\title{
GELOMBANG ULTRASONIK SEBAGAI ALAT PENGUSIR TIKUS MENGGUNAKAN MIKROKONTROLER ATMEGA 8
}

\author{
Denny Wijanarko, Ika Widiastuti, Andriani Widya
}

\begin{abstract}
ABSTRAK
Rats are rodents that cause harm, both at home and in industry. There are several known ways to repel and eradicate rodents such as rat poison, mouse picker, and electric rat repellent. In an effort to reduce the negative impact of using toxins to control mice, one alternative way that can be used is to use ultrasonic waves. Mice are one animal that is sensitive to ultrasonic waves because the mice have a hearing range of between 5-60 kHz. But under certain conditions can exceed up to $100 \mathrm{kHz}$. This study aims to design a prototype for ultrasonic ultrasonic wave test based on microcontroller. The ultrasonic waves generated from the NE555 module have been measured using an oscilloscope of a certain frequency to be removed by the buzzer. And tested in mice to obtain data frequency keberapa very annoying hearing rats.
\end{abstract}

Kata kunci : Tikus, gelombang ultrasonik, mikrokontroler, ATmega 8, Modul NE555.

\section{Pendahuluan}

Tikus merupakan hewan pengerat yang mendatangkan kerugian, baik di rumah maupun industri. Tikus yang berkeliaran di dalam rumah (Rattus rattus, Rattus tanezumi dan jenis lain) merupakan hal yang cukup menjengkelkan bagi banyak orang. Selain menjijikkan, tikus juga dapat mengganggu kesehatan.

Ada beberapa cara yang sudah dikenal untuk mengusir dan membasmi tikus seperti racun tikus, penjepret tikus, dan pengusir tikus elektrik. Cara-cara tersebut mungkin efektif tetapi masih memiliki kelemahan. Perangkap yang diberi makanan dengan racun tikus dapat menimbulkan bau menyengat yang disebabkan oleh tikus yang telah mati

Perkembangan ilmu pengetahuan dan teknologi, terutama di bidang elektronika salah satu sistem yang ditawarkan untuk mengusir tikus adalah teknologi suara ultrasonik Tikus merupakan salah satu hewan yang peka terhadap gelombang ultrasonik karena tikus memiliki jangkauan pendengaran antara 5-60 kHz (Heffner dan Heffner 2007). Namun dalam kondisi tertentu dapat melebih hingga $100 \mathrm{kHz}$.

Penelitian ini bertujuan untuk merancang prototype untuk pengujian gelombang ultrasonik pengusir tikus berbasis mikrokontroler. Gelombang ultrasonik yang dibangkitkan dari modul NE555 telah diukur menggunakan osiloskop dengan frekuensi tertentu untuk dapat dikeluarkan oleh buzzer. Dan diujikan pada tikus guna mendapatkan data frekuensi keberapa yang sangat mengganggu pendengaran tikus.

\subsection{Rumusan Masalah}

Dari uraian tersebut maka dapat dirumuskan beberapa masalah yang timbul :

a) Bagaimana merancang alat pengusir tikus menggunakan gelombang ultrasonik berbasis mikrokontroler ATmega 8?

b) Bagaimana membuat alat pengusir tikus secara otomatis berbasis mikrokontroler ATmega 8?

c) Bagaimana cara membangkitkan suara ultrasonik menggunakan modul NE555?

\subsection{Tujuan}

Tujuan penelitian ini adalah merancang merancang prototype untuk menguji gelombang ultrasonik pada tikus berbasis mikrokontroler ATmega 8 sebagai pengontrol.

\subsection{Manfaat \\ Manfaat penelitian adalah membantu meringankan pekerjaan manusia dalam menangani masalah tikus dirumah. Hal ini dimanfaatkan dalam upaya mendapatkan teknik pengendalian tikus yang berkaitan dengan}


pemanfaatan gelombang suara ultrasonik yang tidak disukai tikus.

\section{TINJAUAN PUSTAKA}

\subsection{Tikus Rumah (Rattus tanezumi)}

Menurut Kamus Besar Bahasa Indonesia tikus adalah binatang pengerat dan merupakan hama yang mendatangkan kerugian, baik di rumah maupun di sawah. Tikus adalah binatang berbulu, berekor panjang, dan pada rahangnya terdapat sepasang gigi seri berbentuk pahat, umumnya berwarna hitam dan kelabu.

Tikus hitam yang berasal dari Asia ini merupakan jenis tikus yang tinggal di dalam rumah. Tikus rumah (Rattus tanezumi) adalah hewan yang masih satu kerabat dengan tikus jenis mencit laboratorium (Mus musculus). Spesies ini sangat dominan, terdapat hampir di seluruh dunia, disebut juga tikus rumah (tikus atap).

\subsection{Gelombang Ultrasonik}

Gelombang bunyi atau yang dikenal sebagai gelombang akustik adalah gelombang mekanik yang dapat merambat dalam medium zat padat, cair dan gas (Sutrisno, 1988). Gelombang bunyi menurut besar frekuensinya dibedakan menjadi tiga. Infrasonik untuk bunyi dengan frekuensi dibawah $20 \mathrm{~Hz}$. Audiosonik untuk bunyi dengan frekuensi antara $20 \mathrm{~Hz}$ hingga $20 \mathrm{kHz}$. (Resnick dan Halliday, 1978).

Secara matematis gelombang ultrasonik dapat dirumuskan sebagai berikut :

$$
\mathrm{S}=\mathrm{v} . \mathrm{t} / 2
$$

Dimana s adalah jarak dalam satuan meter, $\mathrm{v}$ adalah kecepatan suara yaitu $344 \mathrm{~m} /$ detik dan t adalah waktu tempuh dalam satuan detik. Ketika gelombang ultrasonik menumbuk suatu penghalang maka sebagian gelombang tersebut akan dipantulkan sebagian diserap dan sebagian yang lain akan diteruskan. Gelombang yang diserap akan dihitung oleh komparator dan diteruskan menjadi bilangan binari.

\subsection{Mikrokontroler}

Menurut Ibnu Malik (2009:1), bahwa "Mikrokontroler adalah sebagai sebuah sistem komputer yang dibangun pada sebuah keping (chip) tunggal".

Mikrokontroler adalah sebuah system microprocessor dimana didalamnya sudah terdapat CPU, ROM, RAM, I/O, Clock dan peralatan internal lainnya yang sudah saling terhubung dan terorganisasi (teralamati) dengan baik oleh pabrik pembuatnya dan dikemas dalam satu chip yang siap pakai. Sehingga kita tinggal memprogram isi ROM sesuai aturan penggunaan oleh pabrik yang membuatnya (Winoto, 2008:3).

\subsection{Mikrokontroler ATmega 8}

Menurut Djiwo $\mathrm{H}$, Joko $\mathrm{S}$ dan Desi B Mikrokontroler ATmega 8 merupakan seri mikrokontroler 8-bit buatan Atmel Corp. yang memiliki arsitektur AVR (Alf and Vegard's Risc Processor. Mikrokontroler ATmega8 mempunyai 28 pin dengan fasilitas cukup lengkap yaitu 23 jalur Input atau Output, 8KByte In System Programmable Flash, 512 bytes EEPROM, 1 Kbytes Internal SRAM, Internal ADC, Timer atau Counter, SPI, dan USART.

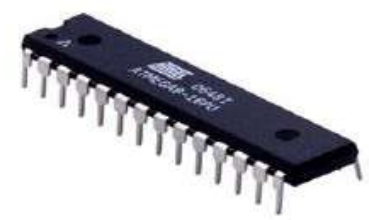

\section{Gambar 1 ATmega 8}

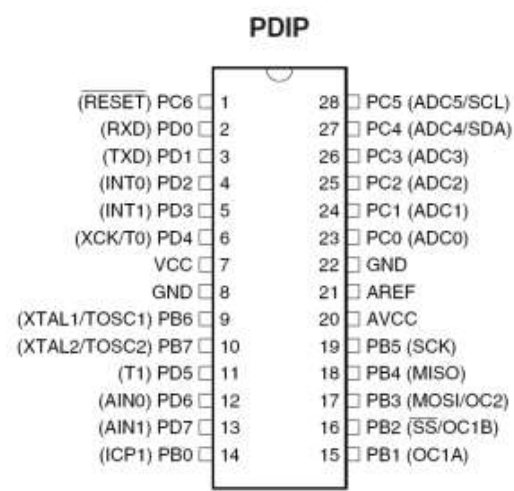

Gambar 2 Konfigurasi pin ATmega8

\subsection{Bahasa C}

Bahasa C merupakan bahasa pemrograman tingkat menengah. Pada tahun 1972 bahasa C pertama kali dirancang oleh Dennis M. dan Brian W. Kernighan mempublikasikan bahasa $\mathrm{C}$ melalui The C Programing Language sehingga bahasa $C$ dikenal banyak orang. Pada tahun 1989 akhirnya bahasa $\mathrm{C}$ distandarisasi ANSI (American National Standart Institute) sehingga menjadi bahasa pemrograman standar hingga saat ini. Kompilernya dapat dibuat pada beberapa platform yang berbeda. (Antonius Rahmat C, 2010:49). 


\subsection{Codevision AVR}

Codevision AVR merupakan sebuah software cross-compiler Bahasa C, Integrated Development Environment (IDE) dan Program Generator otomatis yang khusus dirancang untuk mikrokontroler keluarga Atmel AVR Mikrokontroler. Program ini dirancang untuk dijalankan pada sistem operasi XP, Vista, dan windows 7 arsitektur 32 bit atau 64 bit. Pengisian program ini dapat dilakukan menggunakan compiler yang selanjutnya diprogram ke dalam mikrokontroler menggunakan fasilitas yang sudah disediakan oleh program tersebut. Codevision AVR mempunyai suatu keunggulan dari compiler lain, yaitu adanya codwizard, fasilitas ini memudahkan kita dalam inisialisasi mikrokontroler yang akan kita gunakan (Heryanto dan Adi, 2008).

\subsection{Proteus}

Proteus adalah sebuah software simulasi untuk mendesain rangkaian. Proteus mengkombinasikan program ISIS untuk membuat skematik desain rangkaian dengan program ARES untuk membuat layout PCB dari skematik suatu rangkaian. Proteus memiliki kemampuan untuk mensimulasikan hasil rancangan baik digital maupun analog atau gabungan keduanya, mendukung simulasi yang menarik dan simulasi secara grafis, mendukung simulasi berbagai jenis mikrokontroler. Mendukung open architecture sehingga kita bisa memasukkan program seperti $\mathrm{C}++$ untuk keperluan simulasi, mendukung pembuatan $\mathrm{PCB}$ yang di-update secara langsung dari program ISIS ke program pembuat PCB-ARES (Ali, dk., 2013).

\subsection{NE555 Modul Pembangkit Frekuensi}

IC pewaktu 555 adalah sirkuit terpadu (chip) yang digunakan dalam berbagai timer, pulsa generasi, dan osilator aplikasi. 555 dapat digunakan untuk menyediakan penundaan waktu, sebuah osilator, dan sebagai elemen flipflop. Disediakan hingga empat sirkuit waktu di satu paket. Diperkenalkan pada tahun 1971 oleh Signetics, Modul ini digunakan sebagai pembangkit sinyal gelombang persegi. Sinyal gelombang digunakan untuk pengembangan eksperimental. Frekuensi gelombang dapat diatur dari $20 \mathrm{kHz}-150 \mathrm{kHz}$ menggunakan jumper dan trimmer.

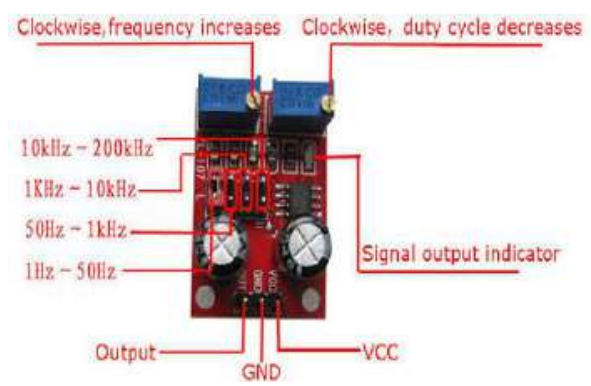

\section{Gambar 3 NE555 Modul Pembangkit Frekuensi}

\subsection{LCD}

LCD atau Liquid Crystal Display adalah sebuah peralatan elektronik yang berfungsi untuk menampilkan output sebuah sistem dengan cara membentuk suatu citra atau gambaran pada sebuah layar. Secara garis besar komponen penyusun LCD terdiri dari Kristal cair (liquid crystal) yang diapit oleh 2 buah elektroda transparan dan 2 buah filter polarisasi (polarizing filter).

Pada umumnya LCD yang dijual di pasaran sudah memiliki integrated circuit tersendiri sehingga para pemakai dapat mengontrol tampilan LCD dengan mudah menggunakan mikrokontroler untuk mengirimkan data melalui pin-pin input yang sudah tersedia.

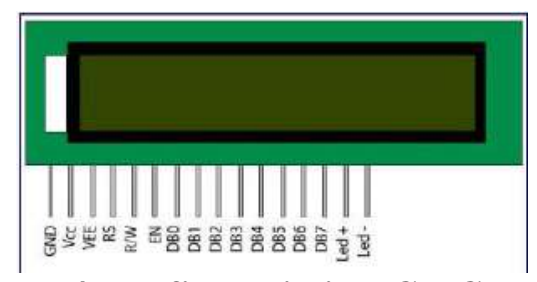

\section{Gambar 4 Konfigurasi pin LCD Character $16 \times 2$}

\subsection{Osiloskop}

Osiloskop adalah alat ukur besaran listrik yang dapat memetakan sinyal listrik. Dengan mengunakan osiloskop dapat mengetahui besaran-besaran pada sinyal listrik seperti tegangan, frekuensi, periode dan bentuk sinyal dari objek yang diukur. Selain itu dengan osiloskop juga dapat membedakan gelombang AC dan gelombang DC, serta dapat juga melihat atau mendeteksi gangguan-gangguan dalam sistem transmisi atau penyaluran seperti gangguan noise. 


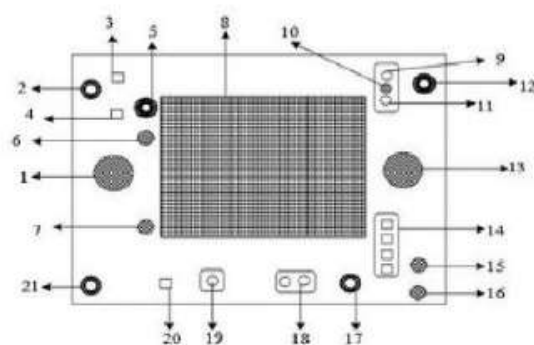

Gambar 5 Bagian-Bagian Osiloskop

Ada beberapa jenis tegangan gelombang yang akan diperlihatkan pada layar monitor osiloskop, yaitu :

1. Gelombang sinusoida

2. Gelombang blok

3. Gelombang gigi gergaji

4. Gelombang segitiga.

Cara menghitung frequency tiap detik. Dengan rumus sebagai berikut :

$\mathrm{F}=1 / \mathrm{T}$ dimana $\mathrm{F}=$ frekuensi $\operatorname{dan} \mathrm{T}=$ waktu

\section{METODE KEGIATAN}

Metode yang digunakan dalam perancangan gelombang ultrasonik sebagai alat pengusir tikus antara lain meliputi proses-proses seperti pada Gambar 6.

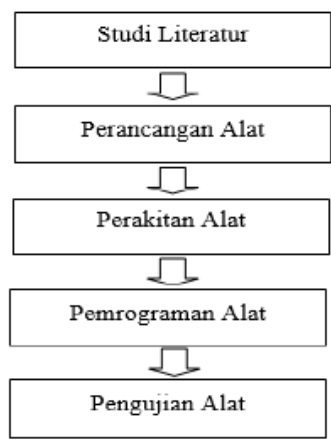

\section{Gambar 6 Tahapan Metode Kegiatan}

\section{HASIL DAN PEMBAHASAN}

Di dalam perancangan pengembangan gelombang ultrasonik sebagai alat pengusir tikus pada tugas akhir ini, ada tiga bagian utama dasar dari perancangan yang pertama yaitu sensor proximity yang bekerja sebagai input atau memberi masukan berupa data analog, modul ADC (Analog to Digital Converter) yang terdapat pada mikrokontroler yang mempunyai fungsi untuk merubah data analog ke data digital yang di proses oleh mikrokontroler dan selanjutnya data tersebut di proses kemudian di keluarkan dalam bentuk suara dengan buzzer dan hasilnya akan ditampilkan kedalam LCD.

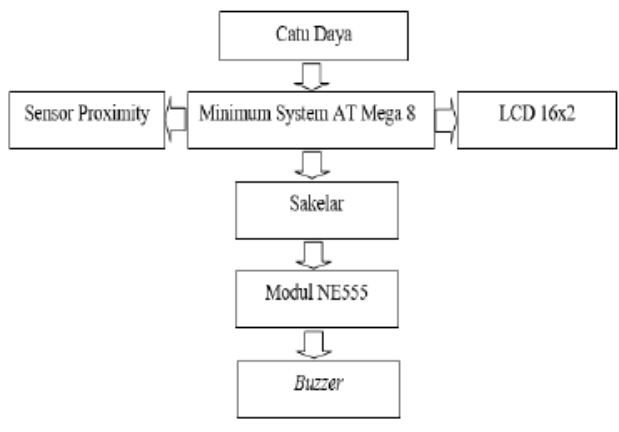

Gambar 7 Gambaran Sistem

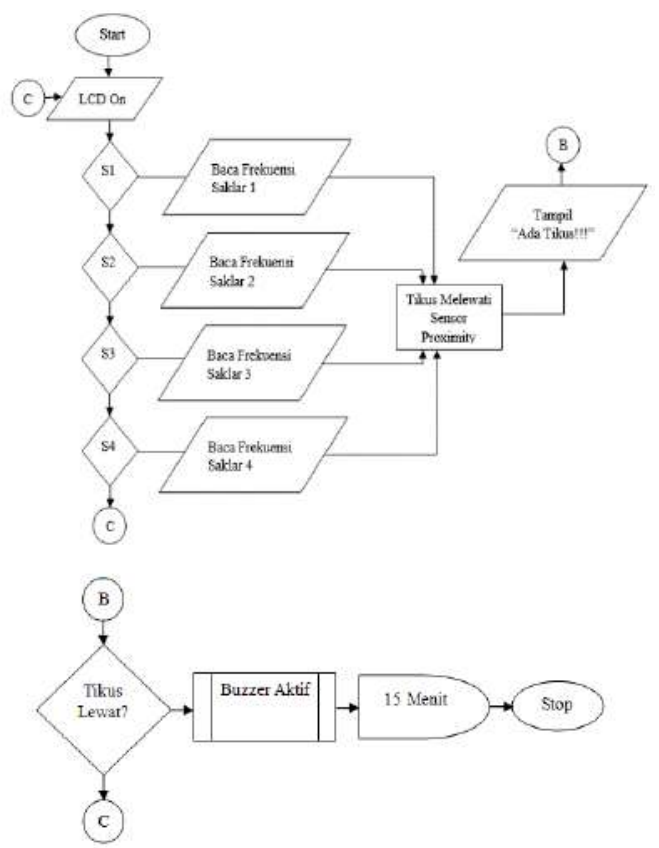

Gambar 8 Flowchart

Flowchart diatas menjelaskan bahwa ketika rangkaian sudah terhubung dengan catu daya $12 \mathrm{~V}$, LCD secara otomatis On dan kondisi awal keempat sakelar dalam keadaan off. Jika menekan sakelar 1 maka frekuensi yang dibangkitkan adalah modul NE555 1, jika menekan sakelar 2 maka frekuensi yang dibangkitkan adalah modul NE555 2, jika menekan sakelar 3 maka frekuensi yang dibangkitkan adalah modul NE555 3, dan jika menekan sakelar 4 maka frekuensi yang dibangkitkan adalah modul NE555 4. Apabila tikus telah melewati sensor proximity, maka LCD akan menampilkan tulisan “Ada Tikus!!!”, dan 
buzzer akan aktif sesuai frekuensi pada sakelar yang telah dipilih. Begitu seterusnya apabila menekan sakelar berikutnya sampai batas waktu 15 menit, kondisi akan stop dan kembali pada start.

Skematik keseluruhan dari alat pengusir tikus ini disajikan pada gambar berikut.

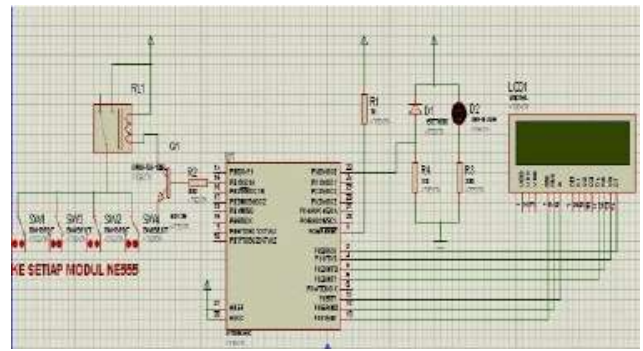

Gambar 9 Skematik Keseluruhan

Sedangkan untuk hasil rangkaian keseluruhan ditunjukkan pada gambar di bawah ini.

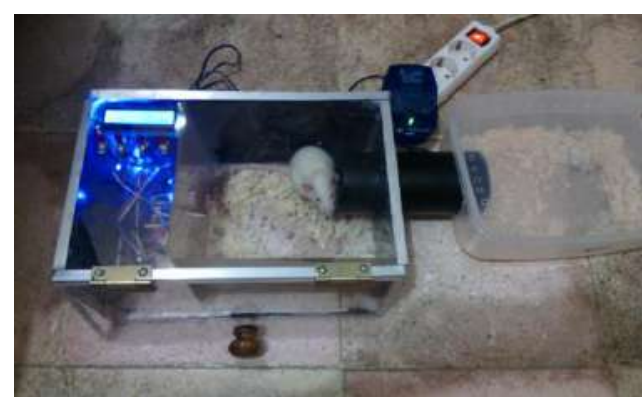

Gambar 10 Rangkaian Keseluruhan Alat

Pengujian fungsi alat

Pengamatan perilaku tikus sebelum diuji oleh alat.

\begin{tabular}{|l|c|l|l|}
\hline $\begin{array}{c}\text { Hari } \\
\text { ke- }\end{array}$ & Tikus 1 & Tikus 2 & \multicolumn{1}{|c|}{ Tikus 3 } \\
\hline 1 & Normal,makan & $\begin{array}{l}\text { Normal, } \\
\text { makan }\end{array}$ & $\begin{array}{l}\text { Normal, } \\
\text { makan }\end{array}$ \\
\hline 2 & Normal,makan & $\begin{array}{l}\text { Normal, } \\
\text { makan }\end{array}$ & $\begin{array}{l}\text { Normal, } \\
\text { makan }\end{array}$ \\
\hline 3 & Normal,makan & $\begin{array}{l}\text { Normal, } \\
\text { makan }\end{array}$ & $\begin{array}{l}\text { Normal, } \\
\text { makan }\end{array}$ \\
\hline 4 & Normal,makan & $\begin{array}{l}\text { Normal, } \\
\text { makan }\end{array}$ & $\begin{array}{l}\text { Normal, } \\
\text { makan }\end{array}$ \\
\hline
\end{tabular}

Adapun hasil kesimpulan dari pengujian alat terhadap tikus dalam 3 hari dan 2 kali perulanganakan disajikan pada tabel di bawah ini.

\begin{tabular}{|c|c|c|c|c|}
\hline $\mathbf{N}$ & Fre & Tikus & Tikus & Tikus \\
$\mathbf{0}$ & $\mathbf{k}$ & $\mathbf{1}$ & $\mathbf{2}$ & $\mathbf{3}$ \\
\hline
\end{tabular}

\begin{tabular}{|l|l|l|l|l|}
\hline & $\begin{array}{c}\mathbf{( k} \\
\mathbf{H z}\end{array}$ & & & \\
\hline 1 & 20 & $\begin{array}{l}\text { Sedikit } \\
\text { menjau } \\
\text { h }\end{array}$ & $\begin{array}{l}\text { Agak } \\
\text { menjauh } \\
\text { Tidak } \\
\text { makan }\end{array}$ & $\begin{array}{l}\text { Agak } \\
\text { menjauh }\end{array}$ \\
\hline 2 & 50 & $\begin{array}{l}\text { Tergan } \\
\text { ggu, } \\
\text { bingun } \\
\text { g, tidak } \\
\text { makan }\end{array}$ & $\begin{array}{l}\text { Bingung } \\
\text { dan } \\
\text { menjauh }\end{array}$ & $\begin{array}{l}\text { Mencak } \\
\text { ar - } \\
\text { cakar }\end{array}$ \\
\hline 3 & 100 & $\begin{array}{l}\text { Tidak } \\
\text { terpeng } \\
\text { aruh }\end{array}$ & $\begin{array}{l}\text { Tidak } \\
\text { terpenga } \\
\text { ruh }\end{array}$ & $\begin{array}{l}\text { Tidak } \\
\text { terpenga } \\
\text { ruh }\end{array}$ \\
\hline 4 & 150 & $\begin{array}{l}\text { Sangat } \\
\text { tidak } \\
\text { terpeng } \\
\text { aruh }\end{array}$ & $\begin{array}{l}\text { Tidak } \\
\text { Terpeng } \\
\text { aruh }\end{array}$ & $\begin{array}{l}\text { Tidak } \\
\text { Terpeng } \\
\text { aruh }\end{array}$ \\
\hline
\end{tabular}

\section{KESIMPULAN DAN SARAN}

5.1 Kesimpulan

1. Pada frekuensi $20 \mathrm{kHz}$ perilaku tikus agak terpengaruh dan tetap makan

2. Pada frekuensi $50 \mathrm{kHz}$ perilaku tikus sangat terganggu, kebingungan dan tidak makan

3. Pada frekuensi $100 \mathrm{kHz}$ perilaku tikus tidak terpengaruh dan tetap makan

4. Pada frekuensi $150 \mathrm{kHz}$ perilaku tikus tidak terpengaruh dan tetap makan

5. Frekuensi yang paling rentan untuk mengganggu pendengaran tikus yaitu frekuensi $50 \mathrm{kHz}$.

\subsection{Saran}

1. Alat ini menggunakan atmega 8 sehingga bagi peneliti selanjutnya sebaiknya mencoba menggunakan alat yang berbeda seperti Arduino, Atmega 8535 dll.

2. Buzzer yang digunakan adalah buzzer biasa. Akan lebih baik jika menggunakan speaker yang berspesifikasi sesuai.

3. Ditambahnya frekuensi pengujian untuk mendapatkan hasil percobaan yang lebih banyak.

4. Terbentuknya alat pengusir tikus dengan deteksi kamera dan diolah menggunakan Pengolah Citra Digital yang secara khusus hanya dapat mengusir tikus saja. 
5. Menggunakan sensor ping parallax agar mendapatkan jangkauan deteksi obyek yang lebih luas.

\section{DAFTAR PUSTAKA}

Cara kerja osiloskop, (http://www.quantummobile.com/artikel/penggunaanalatukur/63-cara-kerja-osciloscope-.html)

Djiwo H. 2009. Pemantauan suhu dengan mikrokontroler atmega8 pada jaringan lokal. Jurnal seminar nasional VSdm teknologi nuklir Yogyakarta(Online), http://jurnal.sttn-batan.ac.id /wpcontent/uploads/2010/03/B42\%20_Djiwo _. Pdf. Diakses tanggal 10 Januari 2014

Heryanto M.A. dan Adi W.P. "Pemrograman Bahasa C untuk Mikrokontroler ATMEGA 8535". Penerbit Andi. 2008.

Heffner, Henry, dkk. 1985. Sound localization in wild Norway rats (Rattus norvegicus). Hear Res. 19(2):151-5.

Heffner, Henry. 2007. Hearing Range of Laboratory Animals. Journal of the American Association for Laboratory Animal Science.

Http://pdf1.alldatasheet.com/datasheetpdf/view/ 80247/ATMEL/ATMEGA8.html

Http://www.e-jurnal.com/2014/02/penyakityang-disebabkan-oleh-tikus.html

Http://www.microchip.com/wwwproducts/en/A Tmega8

Https://www.engineersgarage.com/electroniccomponents/16x2-lcd-module-datasheet

Malik, Ibnu, dkk. 2009. ANEKA PROYEK Mikrokontroler PIC16F84/A. Jakarta: PT Elex Media Komputindo.

Rachmat, Antonius. 2010. Algoritma dan Pemrograman Dengan Bahasa C Konsep, Teori Dan Implementasi. Yogyakarta: ANDI
Sutrisno. 1988. Gelombang dan Optik, seri Fisika Dasar Jilid 2. Bandung : ITB

Wardhana, Lingga 2006, Belajar Sendiri Mikrokontroler AVR Seri ATMega32 Simulasi, Hardware, Aplikasi, Andi Offset, Yogyakarta.

Wasito S. 2004. Data Sheet Book 1. Jakarta: PT Elex Media Komputindo.

Winoto,Ardi.2008. Mikrokontroler AVR ATMega 8/32/16/8535 dan Pemrogramannya dengan Bahasa C pada WinAVR. Bandung : Informatika.

www.alldatasheet.com/ NE555 Frekuensi Adjustable Pulse Generator Module. 